\title{
Nutrition Analysis of "Sujakaju” as a Functional Drink of Health
}

\author{
Laksmyn Kadir (Corresponding Author) \\ Department of Biology, Faculty of Mathematics and Natural Sciences \\ Universitas Negeri Gorontalo, \\ Jendral Sudirman Street No.6, Gorontalo, 96128, Indonesia \\ E-mail: laksmyn04@gmail.com \\ Syam S. Kumaji, \\ Department of Biology, Faculty of Mathematics and Natural Sciences \\ Universitas Negeri Gorontalo, \\ Jendral Sudirman Street No.6, Gorontalo, 96128, Indonesia \\ E-mail: syam_bio@ung.ac.id \\ Wirnangsi D. Uno \\ Department of Public Health, Faculty of Sport and Health Science \\ Universitas Negeri Gorontalo, \\ Jendral Sudirman Street No.6, Gorontalo, 96128, Indonesia \\ E-mail: asi_1403@ung.ac.id
}

Received: July 8, 2018 Accepted: September 1, 2018 Published: September 3, 2018

doi:10.5296/jfs.v7i1.13369 URL: http://doi.org/10.5296/jfs.v7i1.13369

\begin{abstract}
Malnutrition, poverty and abundant corn crops are the factors that provide the potential for innovation to create "Sujakaju" (corn-soy mil). The innovation aims to tackle the issues in
\end{abstract}




\section{MInstitute Macrothink $_{\text {Int }}$}

children health and welfare in Gorontalo. The purpose of this study is to generate the proper formulation of a combination of well-nutrition corn-soy milk. The study employed experimental method with four treatments; each treatment group consumes different kind of corn-soy milk, i.e. milk of pulo (waxy) corn and soybean, Kiki corn and soybeans, hybrid corn and soybean, and from sweet corn and soybean with ratio of 50:50, 100:50 and 150:50 respectively. The results show that milk from mixture pulo corn and soybean suits the most for well-nutrition corn-soy milk by the composition ratio of 150:50, in which it contains the highest carbohydrate and protein nutrition and the lowest fat, compared to the treatment of 50:50 and 100:50 ratios.

Keywords: Corn, Green beans, Nutrition, Organolepti

\section{Introduction}

Gorontalo is among the regions with largest corn production in Indonesia. The corn production continues to rise significantly since the government released the agropolitan program of encouraging its society to cultivate corn. In 2002, the corn production of Gorontalo was still in the level of 245.284 tons. The crops were distributed to all over Indonesia, and some were exported overseas (State Department of Agricultural Affairs, 2003). However, it is ironic that the health status of Gorontalo society somehow is not in accordance with the abundant corn crops. This is due to the census which exposes the high level of people who suffer from malnutrition in Gorontalo.

Packed with a good amount of carbohydrate and with almost similar calories, corn is suitable to replace rice to be the daily staple. Aside from that, corn is also used commonly in sectors of food, chemical, and pharmaceutical industries. In the form of kernels, corn can be processed into various foods, e.g. corn flour, corn rice, and snacks (popcorn and corn nuts). Corn is also transformed into frying oil, margarine, and food formula. Moreover, corn starch is a common use in pharmaceutical industry and as food ingredients, namely for ice cream, cake, and milk.

There are several common local breeds of corn in Gorontalo, e.g. pulo (waxy) corn, kiki corn, hybrid corn, and sweet corn. In Gorontalo, aside from utilization as a daily staple, one way to consume corn is to process it into milk. However, to be consumed by children, corn milk lacks amino acid. To tackle the solution, and as an effort of food fortification, it is possible to add soybean into corn milk. Moehji (1982) once emphasizes that soybean is considered to have properties of complex protein. The limiting amino acid of corn is lysine; meanwhile, in soybean, the limiting amino acid is methionine (Winarno, 1997). Moehji further asserts that blending corn and soybean can complete each other's amino acid contents as well as other nutrition.

It is undeniable that nutrition fulfilment contributes significantly to the optimal development of a child's health. Protein is essential for a child, as it is the source of the human immune system (immunoglobulin). Therefore, a direct red line can be drawn between nutrition and immune system. One who lacks nutrition is more likely to have weak immune system, thus, making the person more susceptible to disease. It is a down-spiral cycle, which when a person is infected by the disease, the less he or she will eat, and eventually, the more prone he or she is from malnutrition. 


\section{Macrothink

Such illustration draws the researcher's concern to carry out a study to generate a precise formulation of a mixture of well-nutrition soybean and corn milk

\section{Materials and Methods}

The research took place in microbiology and chemical laboratories of Faculty of Mathematics and Natural Sciences of Gorontalo State University. The whole phases of research (from preparation to result presentation) were conducted for three months, from March until May 2016

\subsection{Research Tools and Material}

The research comprised tools as follows: blender, knife, $100 \mathrm{ml}$ measuring cup, container, $100 \mathrm{ml}$ beaker, chopping board, waterbath, analytical scale, funnel, filter, aluminium foil, thermometer, and stirrer. Also, the research material included pulo (waxy) corn, kiki corn, hybrid corn, sweet corn, soybean (Phaseolus radiatus L.), sugar, and water.

\subsection{Research Procedures}

The study employed steps as follows:

\subsubsection{Making Corn-Soy Milk}

The process of making corn-soy milk uses ratio of 1:1 (50 grams of corn:50 grams of soybean), 2:1 (100 grams of corn:50 grams of soybean), and 3:1 (150 grams of corn:50 grams of soybean)

The process of making corn-soy milk involves:

- Cleanse the corn and soybean kernel with water.

- Soak the soybean kernel in cold water for four hours; the water is then replaced every two hours.

- Boil the soybean in hot water of 85 until $90 \mathrm{oC}$ for 15 minutes, let the temperature to cool down, and remove the boiling water. The same process goes to corn, only with six minutes of boiling time.

- Grind and blend the soybean and corn in a blender, add 1,5 liters of $80 \mathrm{oC}$ water

- Filter the mixture of corn and soy to get the filtrate extracts. These filtrate extracts are the raw form of corn-soy milk.

- Boil the raw corn-soy milk by $70^{\circ} \mathrm{C}$ for $8-10$ minutes. While stirring it, add $12 \%$ of sugar. When the process finishes, let the milk cool down to a room temperature.

\subsubsection{Nutrition Analysis of Corn-Soy Milk}

\subsubsection{Carbohydrate Test}

The carbohydrate test employed Phenol method, as it can measure the total carbohydrate of liquid food and food extracts, and measure the total amount of sugar of prepared samples.

\subsubsection{Fat Test}

The fat test comprised Babcock method, in which it measures the fat substance level of milk in emulsion form.

\subsubsection{Protein Test}

The research conducted Kjeldahl method to measure nitrogen level of the milk. The method involved steps i.e. destruction, distillation, and titration. (Sudarmadji in Biahimo, 2008). 


\section{Results}

The result displays the nutrition analysis of corn-soy milk, shown in Table 1.

Table 1. Nutrition Analysis of Corn-soy Milk

\begin{tabular}{lllll}
\hline Treatment & Group & Carbohydrate & Protein & Fat \\
\hline \multirow{2}{*}{$50: 50$} & JH*KH & 0.1103 & 10.3603 & 12.3273 \\
& JK*KH & 0.0080 & 10.2430 & 11.4227 \\
& JP*KH & $\mathbf{0 . 1 2 0 3}$ & $\mathbf{1 0 . 4 2 0 3}$ & $\mathbf{1 1 . 0 4 3 3}$ \\
& JM*KH & 0.0793 & 10.2410 & 13.2630 \\
100:50 & JH*KH & 0.1400 & 10.1883 & 13.0350 \\
& JK*KH & $\mathbf{0 . 1 6 6 3}$ & 10.4860 & 12.9423 \\
& JP*KH & 0.1303 & $\mathbf{1 0 . 7 5 0 0}$ & $\mathbf{1 0 . 7 3 0 0}$ \\
& JM*KH & 0.1103 & 10.5300 & 13.5000 \\
& JH*KH & 0.1200 & 10.0977 & 12.8340 \\
& JK*KH & 0.1310 & 10.6940 & 12.4117 \\
& JP*KH & $\mathbf{0 . 1 9 0 3}$ & $\mathbf{1 0 . 9 5 0 3}$ & $\mathbf{1 0 . 4 4 0 3}$ \\
& JM*KH & 0.1470 & 10.4800 & 14.8950 \\
\hline
\end{tabular}

Note. Jh: bisi-2 hybrid corn, jk: kiki corn, jp: pulo corn, jm: sweet corn, kh: soybean.

The previous table exposes that in treatment ratio of 50:50, mixture group JP*KH (Pulo corn and soybean) contains the highest carbohydrate and protein level of 0.1203 and 10.4203 respectively. In addition, the mixture group also comes with a lowest fat level of 11.04333 . Moreover, in treatment ratio of 100:50, mixture group $\mathrm{JK}^{*} \mathrm{KH}$ (Kiki corn and soybean) scores the highest level of carbohydrate with 0.1663. Concurrently, JP*KH (Pulo corn and soybean) group contains the highest level of protein and lowest fat level of 10.7500 and 10.7300 respectively. Furthermore, in the treatment group of 150:50, mixture JP*KH (Pulo corn and soybean) has the highest carbohydrate and protein level, and the lowest fat level, of $0.1903,10.9503$, and 10.4403 respectively.

Based on the analysis, it is deduced that mixture of Pulo corn and soybean has a complete nutrition for corn-soy milk in the composition ratio of 150:50, in which the group contains more carbohydrate and protein with less fat than 50:50 and 100:50 ratio. In short, the nutrition level of each mixture groups is shown in following Figure 1 to 4 . 


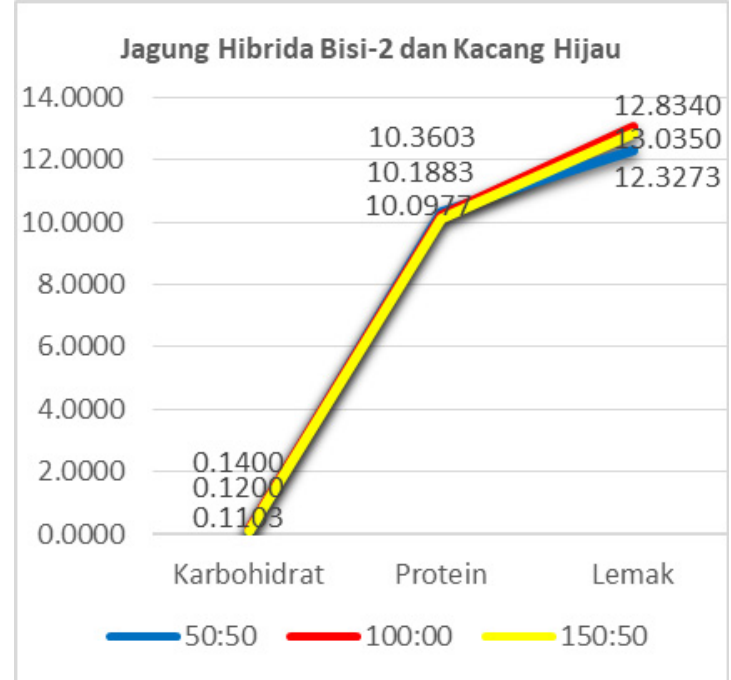

Figure 1. Nutrition analysis of mixture group of hybrid corn and soybean. Details : Jagung Hibrida Bisi-2: Bisi-2 hybrid corn; Kacang Hijau: soybean; karbohidrat: carbohydrate; lemak $=$ fat

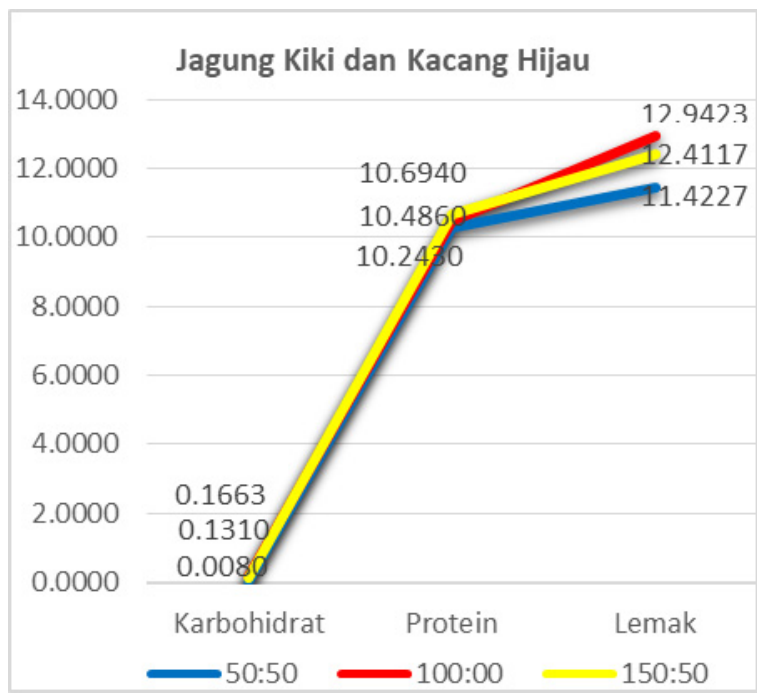

Figure 2. Nutrition analysis of mixture group of Kiki corn and soybean. Details: jagung kiki = kiki corn, kacang hiijau = soybean, karbohidrat: carbohydrate; lemak=fat 


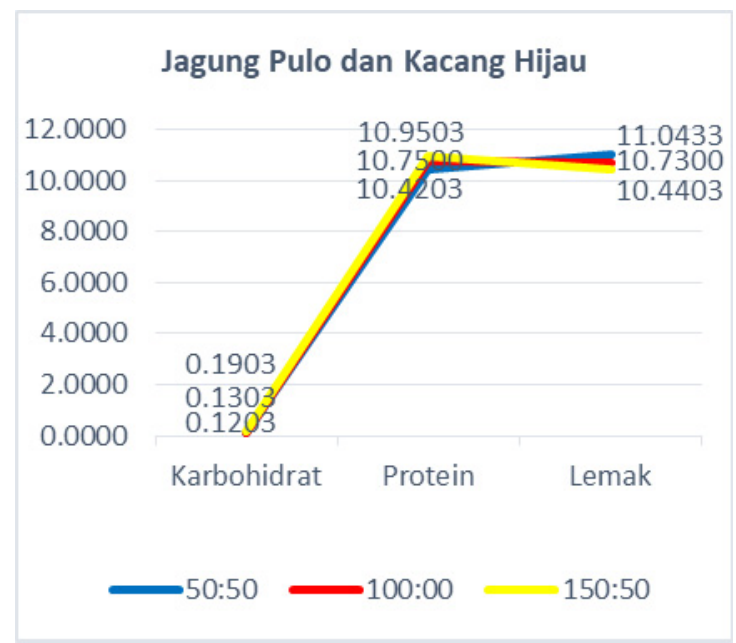

Figure 3. Nutrition analysis of mixture group of Pulo corn and soybean. Details: jagung kiki=kiki corn, kacang hijau= soybean, karbohidrat: carbohydrate; lemak=fat

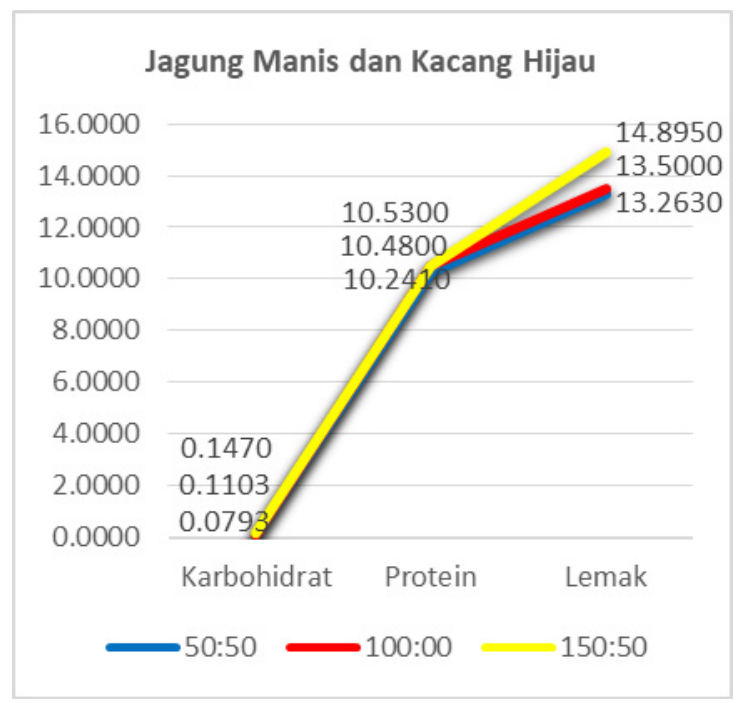

Figure 4. Nutrition analysis of mixture group of sweet corn and soybean. Details jagung manis $=$ sweet corn; kacang hijau $=$ soybean; karbohidrat $=$ carbohydrate; lemak $=$ fat

\section{Discussion}

It is unquestionable that milk contains essential nutrients for a human. People consume purchased cow milk at stores. Nonetheless, its relatively high price and small-scale supply in the stores lowers people's purchase power. Corn-soy milk might be the suitable alternative for Gorontalo society to fulfil the program of empat sehat -lima sempurna (complete nutrition plan).

Moreover, corn-soy milk is made of local food source in which it is a proper combination of corn and soybean. The notion is echoed by Moehji (1982) who argues that combination of both enables a person to fulfil the requirements of nutrition supply, wherein the amino acid between both can complete each other. 


\section{Macrothink}

Furthermore, the result reveals that different combinations of corn breeds with soybean are in average able to generate a fair amount of nutrients needed by human body. Nevertheless, the statistic display that pulo corn-soybean made corn-soy milk generates the most nutrients for the body within the ratio of 150:50, in which the mixture contains the highest level of carbohydrate and protein, with the lowest fat level.

Corn-soy milk from pulo corn and soybean is stated to be the most suitable product to consume since based on the nutrition analysis, it is discovered that Pulo corn contains most starch level among the four corn breeds. Moreover, the mixture is rich in protein since both mixtures' amino acids support each other. As an illustration, Widowati (2011) elaborates that the relatively-low level of lysine amino acid in corn is supported by high level of lysine in soybean. Likewise, low-level of methionine in soybean is completed by a large amount of the substance in corn. Furthermore, pulo corn-soybean corn-soy milk contains the lowest fat level since the high amount of protein decreases the fat level, by that, it is suitable for daily consumption (Winarno, 2010).

\section{Conclusion}

SUJAKAJU made from mixture of pulo corn and soybean with composition ratio of 150:50 which the ideal nutrient content, in which it contains the highest carbohydrate and protein nutrition and the lowest fat, compared to the treatment of 50:50 and 100:50 ratios.

\section{Acknowledgement}

The authors would like to thank those who have participated in this research, the Directorate General of Higher Education of Republic of Indonesia, which has provided funding for this research. The Institute for Research and Community Service of State University if Gorontalo (LPPM-UNG), Department of Biology State University of Gorontalo.

\section{References}

Almatsier, S. (2001). Basic principle of nutrition. Jakarta: PT SUN.

Astawan, M. (2004). Healthy with processed food products. Solo: Tiga Serangkai.

Balibang. (2012). Born superior seed varieties of maize. Jawa timur: Teropong.

BKPPIJ. (2015). Description of superior varieties of maize. Gorontalo: Badan Ketahanan Pangan Dan Pusat Informasi Jagung (BKPPIJ)

Cahyono, B. (2007). Various processed products of Palawijaya. Semarang: Aneka Ilmu.

Cahyono. (2008). Green beans. Cultivation technique and analysis of farming. Semarang: Aneka Ilmu.

Dinas, K. (2015). Malnutrition. Gorontalo: Dinas Kesehatan Provinsi Gorontalo.

Hardinsyah, T. V. (2004). Adequacy of energy, protein, fat and food fiber. in nutritional adequacy score and nutrition labels reference. Jakarta: LIPI, Deptan, Bappenas, BPOM, BPS, Menristek, PERGIZI PANGAN, PERSAGI dan PDGMI.

Legowo, M., Anang., Nurwantoro., Sutarwo. (2011). Food analysis. Semarang: Universitas Diponegoro

Lestari, A. (2013). Nutrition analysis. Yogyakarta: UGM.

Moehji, S. (1982). Nutrition vol. 1. Jakarta: Bhratara Karya Aksara.

Nency, Y., M.T. Arifin. (2015). Malnutrition, lost generation threat. Japan: PPI Jepang. 


\section{Macrothink}

Safuan, L. O., Dirvamena, B., Teguh, W., \& Neli, S. (2014). Variability analysis of corn cultivar pulut (zea mays ceratina kulesh) of local Southeast Sulawesi. Sulawesi Tenggara: Universitas Halu Oleo.

Setyani, S., Medikasari, A., \& Wahyu, I. (2009). Fortification of sweet corn and green beans against physical, chemical and organoleptic properties of sweet corn mung beans. Journal of Industrial Technology and Agricultural Products, 14(2).

Suarni., I. U., \& Firmansyah. (2006). Effect of temperature and drying time on nutrient content of several varieties of corn kernels. Maros: Balitsereal Maros.

Suarni., Widowati, S. (2007). The structure, composition, and nutrition of maize. Puslitbang Tanaman Pangan.

Syam'un, E., Mollah, J., \& Nurfaida. (2012). Growth and production of various genotypes of corn pulutant at various doses of kcl fertilizer. Makassar: UNHAS

Tiommanisyah. (2010). Analysis of rough protein content in soybeans, peanuts and green beans using kjehdal macro method as mixed food substance. Medan: USU.

Trustinah, B. S., Radjit, N., Prasetiaswati., \& Harnowo, D. (2014). Adoption of green bean superior varieties at production center. Malang: Research Institute for Aneka Bean and Ubi Crops.

Widowati, S., \& Wargiono, J. (2011). The role of functional food in improving public health. Bogor: Puslitbangtan

Winarno, F. G. (1997). Food chemistry and nutrition. Jakarta: Gramedia Pustaka Utama.

Winarno, F. G. (2003). Food analysis and nutrition. Jakarta: Gramedia Pustaka Utama.

\section{Copyright Disclaimer}

Copyright for this article is retained by the author(s), with first publication rights granted to the journal.

This is an open-access article distributed under the terms and conditions of the Creative Commons Attribution license (http://creativecommons.org/licenses/by/3.0/). 